ks. Leszek Szewczyk

\title{
Nowe czasopismo „Studia Pastoralne”
}

W 2005 roku minęło 40 lat od zakończenia obrad Soboru Watykańskiego II (1962-1965). Dziedzicząc doktrynalny dorobek ostatniego soboru, zdajemy sobie sprawę, że jego głębia pozostaje wciąż jeszcze w znacznym zakresie nieprzenikniona i kryje bogate inspiracje teologiczno-pasto- 
ralne. Ta świadomość prowokuje do twórczej postawy badawczej, każe podejmować nowe próby docierania do sedna soborowego nauczania oraz rozwijania - w jego świetle - współczesnej teologii, szczególnie zaś tych jej gałęzi, które oprócz charakteru ściśle naukowego odznaczają się wymiarem praktycznym. Taką specyfikę posiadają dyscypliny teologiczne, które ze swej natury pozostają otwarte zarówno na objawienie Boże, jak też na konkretne egzystencjalno-duszpasterskie doświadczenie poszczególnych jednostek lub całych wspólnot religijnych. Chodzi więc o teologię pastoralną, liturgikę, homiletykę, katechetykę, misjologię czy duchowość chrześcijańską. Wyznaczanym przez te dyscypliny obszarom teologiczno-pastoralnym poświęcone są „Studia Pastoralne”, których pierwszy numer ukazał się w tym roku. Redakcja czasopisma wyraża ogromną nadzieję, że zdobędą one na polskim gruncie rangę otwartego dla wszystkich, gwarantującego swobodną i pogłębioną wymianę myśli teologicznych oraz duszpasterskich doświadczeń forum. Czasopismo „Studia Pastoralne” jest rocznikiem; w swej strukturze zawiera następujące działy: artykuły, materiały, recenzje i omówienia, a także sprawozdania. W dziale artykułów wyodrębniają się specyficzne zagadnienia dotyczące wspomnianych wyżej dziedzin teologiczno-pastoralnych.

W pierwszym numerze „Studiów Pastoralnych” dziedzinę teologii pastoralnej reprezentują cztery artykuły. W pierwszym z nich ks. Ryszard Kamiński uświadamia fakt, iż teologia pastoralna wyróżnia się wśród innych dyscyplin teologicznych orientacją egzystencjalną i praktyczną. Jest mianowicie nauką, która zarówno w świetle objawienia Bożego, jak i konkretnego doświadczenia Kościoła rozpoznaje, co powinien on czynić, by móc rozstrzygać o wartości stosowanych przez niego na różnych poziomach pełnionej misji form duszpasterskich, jak też formułować odpowiednie wskazania na przyszłość. Ks. Józef Mikołajec poszerza temat opracowany przez ks. Kamińskiego o zagadnienie metod, jakimi się posługuje i jakimi posługiwać się powinna w danym kontekście historyczno-społecznym teologia pastoralna. Zwraca przy tym uwagę, iż jest to problem dla tej dyscypliny wciąż otwarty, dyskutowany i traktowany przez jej przedstawicieli badawczo. Ks. Marek Łuczak wyjaśnia pomocną, ale też nieodzowną rolę socjologii w procesie precyzowania kontekstu kulturowego, do którego powinny być aplikowane treści objawienia - przekazywane w sposób przystosowany do historyczno-kulturowego kontekstu społecznego. Ks. Łuczak wyjaśnia przy tym ważna sprawę „styku” socjologii i teologii, szczególnie zaś socjologii religii i teologii pastoralnej. Ks. Bogdan Biela omawia aktualne problemy teologii pastoralnej poddając analizie dziedzictwo wybitnego pastoralisty polskiego, jakim był ks. prof. Franciszek Blachnicki. Jego koncepcja teologii czy eklezjologii 
pastoralnej jest wciąż aktualna, a wynikająca z niej wizja cura pastoralis ciągle domaga się głębszego zrozumienia i konsekwentnej realizacji.

Również cztery artykuły dotyczą katechetyki. Najpierw ks. Roman Murawski skłania do zadumy nad katechetyczną misją Kościoła i zwraca uwagę na aktualny stan refleksji nad katechetyką w naszym kraju w okresie posoborowym. Uświadamia przy tym pilną potrzebę wypracowania i stworzenia spójnej teorii katechezy i zachęca tym samym do zabierania głosu na ten istotny i ważny dla polskiej katechetyki temat. Ks. Zbigniew Marek definiuje z kolei katechezę w kategoriach służby człowiekowi. Na podstawie odpowiednich dokumentów wykazuje, że Kościół za nadrzędne zadanie swej duszpasterskiej misji (kierowanej zawsze ku człowiekowi) uważa głoszenie prawdy o tym, że w osobie Jezusa przybliżyło się do ludzi królestwo Boże, a tym samym zbawienie. Temu zbawieniu służy Kościół przepowiadając Dobrą Nowinę na wzór swego Boskiego Mistrza. Ks. Roman Buchta przekonuje o konieczności dowartościowania we współczesnej katechezie Pisma Świętego - prawdziwego źródła dla nauczycielskiej misji Kościoła, a także o potrzebie takiej katechezy, która by prowadziła do rozmiłowania w czytaniu Biblii, do głębszego wnikania w jej treść i w orędzie, z jakim Bóg zwraca się nieustannie do wszystkich ludzi. Ks. Krzysztof Sosna przybliża w swoim artykule trudne, ale dla nauczania katechetycznego istotne zagadnienie przyznania w katechezie odpowiedniego miejsca osobom niepełnosprawnym - szczególnie umysłowo. Problem jest o tyle ważny, że - jak się okazuje -w podręcznikach katechetycznych nie eksponuje się jeszcze wystarczająco tej kwestii, a prowadzone dziś katechezy specjalne stanowią w dużej mierze owoc pracy i dydaktycznych pomysłów poszczególnych katechetów.

Obszar homiletyki wypełniają dwa artykuły. W pierwszym z nich o. Gerard Siwek przypomina o sprawie istotnej wagi, mianowicie że związek homiletyki z teologią pastoralną posiada podstawy zarówno merytoryczne, jak i historyczne. Co prawda był on w przeszłości bardziej lub mniej ścisły, jednak stanowił źródło wzajemnego ubogacenia tych dyscyplin. Bardziej szczegółowe przedstawienie losów owego związku domaga się jeszcze badań, podobnie zresztą jak i dokładniejsze ustalenie relacji zachodzących pomiędzy homiletyką kontekstualną i interdyscyplinarnością (kontekstualnością) pozostałych dziedzin pastoralnych czy też dyscyplin teologicznych w ogólności. Ks. Jan Twardy wychodzi w swym artykule z założenia, że fakt ustanowienia Eucharystii i męka Pańska pozostają ze sobą w ścisłym związku. Dlatego głosiciele kazań pasyjnych powinni - jego zdaniem - częściej o tym mówić. Potrzeba akcentowania Eucharystii w głoszeniu męki Pańskiej motywowana jest w przekonaniu ks. Twardego kontekstem obrzędowym (śpiew Gorzkich żali i głoszenie kazań dokonuje się podczas 
nabożeństwa połączonego z wystawieniem Najświętszego Sakramentu), potrzebą dopracowania mistagogicznego charakteru kazań pasyjnych (owocem zbawczej męki Chrystusa są sakramenty Kościoła - z Eucharystią na czele), potrzebą pogłębienia uczestnictwa wiernych we mszy świętej (może w tym pomóc głoszenie kazań pasyjnych, które uwydatniają ofiarniczy charakter Eucharystii), potrzebą wychowywania słuchaczy kazań pasyjnych do współofiarowania się Bogu w łączności z Chrystusem.

Z dziedziny liturgiki zostają zaprezentowane w pierwszym numerze „Studiów Pastoralnych” trzy artykuły. W pierwszym z nich ks. Jerzy Paliński przypomina, jak się kształtował i jaką drogę rozwoju przebył ruch związany z pobożnością eucharystyczną, a także, jakie są i jak być powinny rozumiane oraz wcielane w życie podstawy dobrze pojętej i rozwijanej pobożności eucharystycznej. Ks. Andrzej Żądło omawia pobożność ludową w adwencie, wyczula na atmosferę tego okresu, łączy ze sobą tematy teologiczne, jakie przenikają obie formy przygotowań na spotkanie z Panem - liturgię i pobożność ludową. Ks. Roman Kuligowski wykazuje, że istotną rolę w liturgii odgrywa piękno. Skoro uczestnictwo wiernych w liturgii ma być świadome, czynne i owocne, to staje się oczywiste, że od odpowiedzialnych za liturgię wymaga się szczególnego uwrażliwienia na estetykę. Miejscem, w którym dokonuje się liturgia, jest świątynia wzniesiona z kamieni. Miejscem zaś spotkania człowieka z Bogiem wzywającym do pięknego życia (czynienia dobra i unikania zła) jest sumienie. Można zatem w sensie przenośnym mówić o „liturgii” dokonującej się w sumieniu człowieka. Również ta „liturgia" woła o piękno partnera dialogu inicjowanego przez Boga.

$\mathrm{Na}$ zakończenie działu artykułów zamieszczono trzy opracowania poświęcone istotnym $\mathrm{z}$ duszpasterskiego punktu widzenia tematom. Ks. Grzegorz Noszczyk podejmuje próbę udzielenia odpowiedzi na pytanie, jaki wkład w rozwój społeczeństwa obywatelskiego mogą wnieść katolicy świeccy, i podkreśla, że właściwie realizowany apostolat świeckich wymaga od laikatu, aby - przy zachowaniu kompetencji, roztropności i profesjonalizmu w działaniu - uczestniczył aktywnie w życiu takiego społeczeństwa. Ks. Wojciech Misztal przenosi czytelnika na płaszczyznę duchowości chrześcijańskiej i stwierdza, że kontakt z naturą ułatwia człowiekowi spotkanie z Bogiem. Tak każą patrzeć na człowieka i przyrodę czołowi przedstawiciele duchowości chrześcijańskiej i jej fundatorzy. Ks. Kazimierz Dola zarysowuje panoramę szkolnictwa w rejencji opolskiej w XIX wieku.

W dziale materiałów znajduje się kilka tekstów dotykających spraw szczególnie aktualnych w Roku Eucharystii, wiążących się z kultem eucharystycznym, omawiających eucharystyczną adorację (ks. Jerzy Paliński), zarysowujących cechy polskiej pobożności eucharystycznej (ks. Józef Kudasiewicz) 
i wskazujących na Eucharystię jako pokarm na życie (ks. Tomasz Rusiecki). Podjęty jest też - w formie dialogu prowadzonego przez młodych - temat sensu życia i obecności w nim cierpienia (ks. Janusz Tarnowski); przedstawiono także rezultaty badań nad percepcją nauki o obecności i działaniu Ducha Świętego w Kościele przeprowadzonych w środowisku członków znanego ruchu „Odnowa w Duchu Świętym” (ks. Grzegorz Polok).

W dziale recenzji i omówień zwracają uwagę (oprócz recenzowanych książek o tematyce duszpasterskiej) omówienia trzech dokumentów Kościoła, a mianowicie listu apostolskiego Jana Pawła II pt. Mane nobiscum, Domine (ks. Stanisław Czerwik), instrukcji Kongregacji ds. Kultu Bożego i Dyscypliny Sakramentów pt. Redemptionis sacramentum (ks. Matias Augé CMF) oraz Wskazania i propozycje tejże Kongregacji na Rok Eucharystii (ks. Wojciech Misztal). Całość pierwszego numeru „Studiów Pastoralnych” zamykają sprawozdania z kongresu, sympozjów i naukowych konferencji, jakie miały miejsce w ostatnim czasie w różnych środowiskach teologicznych w Polsce.

Redakcja korzysta z wielu cennych sugestii wypływających od czołowych polskich teologów pastoralistów, którzy tworzą radę naukową czasopisma, jednocześnie otwarta jest na wszelkie propozycje płynące ze strony teologów i duszpasterzy. „Studia Pastoralne” są rocznikiem Wydziału Teologicznego Uniwersytetu Śląskiego i na jego adres należy nadsyłać wszelkie sugestie i wnioski. 